\title{
Prezentacje
}

\section{Trauma i niewymowność}

Lauren Berlant

TEKSTY DRUGIE 2018, NR 3, S. 176-195

DOI: $10.18318 /$ td.2018.3.12

\section{Świadectwo i bezosobowość}

„Straszliwie się boję”,,,boję się ciemności”, ,obawiam się wyjść dalej niż do sklepu spożywczego”, „nie wychodzę z domu",,,nocuję u kolegi", ,nie mogę się skupić”,,,drażnią mnie wszystkie dźwięki”, „boję się, że powołają mojego brata do wojska”, ,kiedy odzywają się syreny, robi mi się niedobrze”, ,schudłem 4 kg, załamałem się psychicznie”, "czuję się źle, idąc co noc do schronu”, ,wzdrygam się na widok żołnierzy na ulicy”, "czuję, że wypadłem z szyn, moje życie zupełnie się zmieniło”, ,obawiam się przyszłości”,„nie przestaję brać tabletek nasennych",,śsię w ubraniu”, ,dzieci w schronie są bardzo wzburzone”,,tam, gdzie pracuję, mężczyźni zaczęli dużo pić", ,jestem zdenerwowany”, „nie boję się śmierci, a gwałtownych dźwięków”, "cierpię, że nic mi nie wychodzi”, „mój stan emocjonalny zmienia się z godziny na godzinę”, „wyrzuciłem telewizor, nie mogę więcej słuchać tego języka”, ,,sąsiedzi ciągle rozpowiadają apokaliptyczne plotki",,,jestem zdenerwowany, chodzę ze schronu do mieszkania trzy razy w ciągu nocy”, „myślę, by na zawsze porzucić ten kraj, tak bardzo mnie mdli”, „nadchodzą nowe lęki”.
Lauren Berlant, Trauma and Ineloquence, „Cultural Values" 2001, nr 5, drukza zgodą wydawcy: Taylor \& Francis Ltd, http://www. tandfonline.com

\section{Lauren Berlant -}

George M. Pullman

Distinguished Service Professor na Wydziale Anglistyki Uniwersytetu Chicagowskiego, autorka m.in. Cruel optimism (Duke UP, 2011); The female complaint: the unfinished business of sentimentality in American culture (Duke UP, 2008) $i$ The queen of America goes to Washington City: essays on sex and citizenship (Duke UP, 1997). 
Ostrzeżenie: proszę nie przekazywać tej informacji prasie, a kiedy podawane są którekolwiek fakty, proszę nie łączyć ich z nazwiskiem informatora, gdyż może to zagrażać jego bezpieczeństwu'.

Do mojej skrzynki codziennie wpadały komunikaty z oblężonych miejsc: Kosowa, Iraku, Sri Lanki, Teksasu, Pensylwanii, Chicago. W istocie rzadko jestem ich adresatką, niektórych sama poszukiwałam, inne trafiły do mnie za sprawą internetowych społeczności, do których należę. Bez wskazania osoby są jednak napisane do mnie, tzn. obcej dla innych obcych, których przeżycie zależy od zaangażowania psychologicznego wsparcia (type through type). Poszukują takiej osoby, która odczuwa bliskość do innych w abstrakcyjny sposób, a jednocześnie uporczywie dodaje osobisty element w działaniu na mocy tej bliskości. Podważając w pełni spersonalizowane pojęcie intymności i obowiązku, list-świadectwo burzy zwyczajowe myślenie o przestrzeni geopolitycznej. Walka polityczna tworzy nowe i niezarządzane przestrzenie, ulegające nieustannym przemianom w czasie kryzysu, w szczelinach bombardowań, karmienia, policyjnych interwencji itp. Pozaprawna natura tych przestrzeni pozbawionych zasad jest z kolei odtwarzana w akcie zawłaszczenia retoryki prawniczej przez autora. Rozliczne gatunki prawne: materiał dowodowy, argumentacja i wyrok, pojawiają się tutaj w wypaczonym porządku, aby stworzyć przeciw-publiczność dla reżimu sprawiedliwości, który jeszcze nie powstał. Przyjmując je za pewnik, świadectwo przekracza również zasady tych gatunków, przypisując sobie władzę oczywistości (self-evidence) przeciwstawionej autorytetowi nadawanemu przez instytucje oraz zgodną publiczność. W tym sensie, kierując się pragnieniem utworzenia popularnego archiwum podatnego na powtórzenia oraz potencjalnego miernika społecznej wartości w odróżnieniu od instytucji i norm zwyczajowo postrzeganych jako wyznaczniki tego, co właściwe i sprawiedliwe, list od nieznajomego oznacza także wycofanie zgody autora na normatywność dominacji. Nikt jednak nie wie, wysyłając takie sondy, czy coś uzyska czy nie. Zależy to od tego, czy dana informacja doprowadzi do aktu komunikacyjnego o wystarczającej mocy, aby uznać ją za wiedzę pewna (knowledge of record).

1 Ten cytat składa się z wielu listów przesłanych na przestrzeni lat, a dokładnie pięciu. Zdecydowałam się nie wybierać konkretnego listu, aby zaprezentować mój sąd o traumie, świadectwie i niewymowności, uszanowałam również prośbę w końcowym ostrzeżeniu i pomieszałam kolejność zdań. Ryzykuję zniekształceniem archiwum, z którym styka się Czytelnik. Tak wiele przepadło w wielokrotnych przekładach, że nikt z nas, ośmielam się stwierdzić, nie mógłby opowiedzieć całej prawdy na podstawie materiału dowodowego. 
Oto esej o traumie i niewymowności, bezosobowości i intymności oraz o sile wiedzy świadectwa i ekspertyzie we współczesnych Stanach Zjednoczonych. Traktuje o zmianie w strukturze normatywnej masowej podmiotowości, przesunięciu w obecnym w sferze publicznej standardzie zwyczajnej osobowości z oświeceniowego modelu człowieka racjonalnego, uporządkowanego, dzięki przewadze umysłu nad ciałem, na rzecz obrazu podmiotu, który staje się historyczny za sprawą bliskości traumy². Trauma jest nadzwyczaj trudna do zdefiniowania - przytłaczające zdarzenie, scena wypadku umykającego wymowności historii, dosłowny, niesymbolizowalny znak czystej przemocy lub jej przeciwieństwo, przemocy zastygłej we wzmożonej reprezentacjï. Jakiekolwiek znaczenie nadawano by traumie, moim celem jest zrozumienie jej formalnych wyznaczników; jako kategoria uniwersalna z pewnością sprawia wrażenie niewymagającej omówienia, w celu ujawnienia jej przezroczystości lub pustki. Ten właśnie paradoks wyjaśnia, dlaczego podmiot rozpoznający się jako posttraumatyczny uważany jest za w największym i w najmniejszym stopniu znawcę jej znaczenia - w najmniejszym stopniu, jako że trauma z definicji rozwiewa zasady ciągłości, stabilizujące samowiedzę w czasie i w największym, ponieważ w końcu nikt nie może zostać świadkiem czyjejś historii. Gdy przyjmuje się ją, jak to się teraz często zdarza, za metaforę pojedynczego osobistego i kolektywnego doświadczenia społecznej negatywności, tautologiczne właściwości traumy chronią podmiot za sprawą potwierdzenia ekspertyzy o podstawie roszczenia podmiotu. („Nie mogę już więcej utrzymywać ciągłości siebie jako jednostki/wspólnoty sprawujących kontrolę nad moją historią, nikt nie może jednak odebrać mi mojej traumy). To dar (utraty), który nie przestaje dawać.

Brak precyzji „pojęcia-metafory” traumy nie jest moją winą czy też dowodem na jej deskryptywną pustkę, tak jak większość kategorii nazywanych

2 Rozszerzona wersja tej argumentacji znajduje się w L. Berlant The Subject of True Feeling: Pain, Privacy, and Politics, w: J. Dean Cultural Studies and Political Theory, Cornell University Press, Ithaca 2000, s. 42-62.

3 Trauma: Explorations in Memory, ed. C. Caruth, Johns Hopkins University Press, Baltimore 1995 C. Caruth Unclaimed Experience: Trauma, Narrative, and History, Johns Hopkins University Press, Baltimore 1996; S. Felman, D. Laub Testimony: Crises of Witnessing in Literature, Psychoanalysis and History, Routledge, New York 1991; D. LaCapra Representing the Holocaust: History, Theory, Trauma, Cornell University Press, Ithaca 1996; K. Farrell Post-traumatic Culture: Injury and Interpretation in the Nineties, Johns Hopkins University Press, Baltimore 1998; When Pain Strikes, eds. B. Burns, C. Busby, K. Sawchuk, University of Minnesota Press, Minneapolis 1999. 
pustymi, w istocie przepełniona jest znaczeniem ${ }^{4}$. Każde pojęcie uważane za powszechnik musi przyjąć formę takiej pustki, tejże nieokreślonej i namnażającej się abstrakcji, zachowując pozory formalnej ciągłości, przekraczającej jakąkolwiek konkretną treść. To dlatego teoretycy traumy nie przestają zwracać się ku psychoanalizie i teorii poezji, do wyrażonego w nich wyczulenia na rytm, wpływ i powtórzenie, w celu opisania tego, co traumatyczne. Bez względu na treść istnieje szczególna przyjemność w zespoleniu trybów: symptomatycznego i poetyckiego, które zajmują wystarczająco stałe miejsce, aby podmiot miał do czego ciągle powracać. Z drugiej strony koszmar powtórzenia wyznaczanego przez rytm, unicestwiający wykonanie woli, koliduje ze zdolnością do wyobrażenia sobie przestrzeni poza sceną lub wydarzeniem, które zdominowały chwilę obecną. Rozstrzyganie relacji między tymi procesami opisywane jest zazwyczaj za pomocą wyrażenia „przepracowanie”. Ciężka to praca i trudna do uzyskania.

Poddany negacji musi jednak wyrażać się takjakbyjej/jego mowa osiąnnęły jasność, to znaczy już stały się performatywne. To jest, zdania świadectwa przemawiają do takiego czytelnika, który jeszcze nie istnieje, jak gdyby istnienie historycznej osoby było jedynie częścią wspólnotowej umowy, z której autor listu może skutecznie się wycofać. Stąd, „ja” w tym świadectwie, by odwołać się do Hortense Spillers, pojawia się za sprawą funkcji kolektywnej: formuła listu od nieznajomego zaciera granicę między wspólnotową i indywidualną podmiotowością, przemawiającego niejako do świata, lecz poddanego zapośredniczeniu przez niewyszczególnione jednostki5. Cielesny ból, którego zakomunikowanie daje podstawę wezwania do politycznej przemiany czytelnika, nic nie znaczy bez krytycznej woli utrzymania doświadczenia otwartym, co oznacza doświadczanie traumy historii innego oraz przekazywanie jej w taki sposób, aby pozostała traumatyczną dla innych. To właśnie dlatego świadectwo zawsze przybiera formę epistolarną. Jednorazowość takiego kolektywnego wyobrażonego przekształca prywatne w publiczne i na odwrót.

W skrócie retoryczny nastrój tego zapisu jest bezosobowy, obiektywny i intymny. Poza tym uważane za niewypowiadalne, niereprezentowalne prawdy traumatycznego podporządkowania i traumatycznej negacji należy przełożyć na tryby porażki retorycznej, wystarczająco jednak dramatycznej

4 G.C. Spivak Subaltern Studies: An Introduction, w: tejże In OtherWorlds: Essays in Cultural Politics, Routledge, New York 1987, s. 198.

5 H.J. Spillers Mama's Baby, Papa's Maybe: An American Grammar Book, "Diacritics” 1987 No. 2, s. 67. 
w obliczu trwającej przemocy, aby skutecznie zakomunikować traumę jako doświadczenie trzewne i kognitywne. Uruchamiając domniemaną uniwersalność bólu i cierpienia, świadectwa wzywają cię do przemiany za sprawą wiedzy, której nie możesz bezpośrednio poczuć; do zmiany odruchów trzewnych, pozwalając twoim impulsom cielesnym zapisać wydarzenia, o których jedynie czytałeś. Wyznaczają tobie zadanie odnalezienia właściwej relacji do sumienia, to jest przestrzeni wyższego prawa, gdzie stawiasz czoła rozbieżnościom między literą a duchem i podsumowujesz wyniki tej matematycznej operacji. Takie wyzwanie jest niewiarygodnie intymne, powiązane z groźbą wystawienia się na nowo zapośredniczone „ja”, pozbawione odczuwania, a jednocześnie dobrze poinformowane. To w sumieniu dokonujesz obliczeń. Gdy wziąć pod uwagę prawdziwe liczby - tylu zabitych, tylu uwięzionych, tylu naznaczonych potencjalną przemocą - dialektyka świadectwa i bycia świadkiem ma materialne konsekwencje. Albo poświęcasz się nowym, istotnym prawom i praktykom, albo nie. Sam decydujesz się liczyć lub rezygnujesz. To ty docierasz do szerszej publiczności z uzyskaną wiedzą lub nie.

Desperacko domagając się przekazywania historii przez słuchaczy, „ja” w opresji ma związku z tym przeciwstawne cele. Powinno dostarczyć tekstu wypowiadanego z pełnym przekonaniem. Odbiorca musi odczuwać nakaz jego powtarzania, gdyż to jedyny warunek, aby nabrał autorytetu. Jednocześnie musi przyznać, że słowa są niewystarczające, w tym samym stopniu co osoby, sumienia i wiedza jako takie są niewystarczające do wprowadzenia koniecznej przemiany. Nieodpowiedniość słów, które niemniej jednak ujmują scenę opresji, tworzy wewnętrzne obawy, wywołujące w jednostce odczucie, że zmiana świata, w którym mogą dziać się takie historie, stała się właśnie warunkiem jej przeżycia. Te historie muszą działać jak wirus, aby ludzie obciążeni wiedzą o traumie odczuwali nieustające i nieprzyjemne cielesne echo. Negatywność rozpowszechniona jako świadectwo tym samym wytwarza negatywności. Bezosobowość i anonimowość wskazują na niewymowność jako narzędzie zapisu niehumanitarności przemocy w akcie nadpersonalizacji „ty”, lecz wyłącznie w znaczeniu wezwania do działania. Nie liczy się, kim byłeś przed lekturą listu. Nagłaśnianie negatywności musi skutecznie dawać przykład relacji społecznej bez przekształcania jej w istniejącą już rzecz, jako że celem rozpowszechniania przeciw-prawniczego świadectwa o odpodmiotawiającej krzywdzie jest zgłoszenie postulatu przyszłości wykraczającej poza ten list.

Chciałabym zaproponować wyjaśnienie, dlaczego na poziomie retorycznym te historie wypowiadają niewymowne za pomocą sensacyjnej narracji. 
Jest to retoryczny, polityczny i etyczny paradoks, przed którym staje każdy, kto zauważa rosnącą liczbę świadectw przemocy różnego rodzaju. Sue Goulding nazywa opisywany przeze mnie tryb autorstwa świadectwa odegraniem nie-nie negatywności6. Przezwyciężenie negatywności za sprawą sprawczości listu nie znaczy, że negację autora poddano zaprzeczeniu, na wzór wypełnionego otworu lub skutecznie ukojonego lęku, dodania dwóch wartości ujemnych, nawet jeśli list odniósł „sukces” według jakiegoś kryterium. Zamiast tego de-negacja to najlepsze, co możemy sobie wyobrazić w celu społecznej przemiany podporządkowanych egzystencji: resztki świadectwa to także dowód na to, co się wydarzyło. Symptomy, zagęszczające historię, przypominają skamieniałe metafory, które czytelnicy powinni przywrócić do życia.

Wracamy tym samym do problemu etyki krytycznej uwagi: „delikatności słuchania"7. Czym innym jest przebywanie w zmysłowo przytłaczających i otępiających przestrzeniach traumy, czym innym czytanie o takich rzeczach, gdy brak ciał lub ich obrazów, które stały się nośnikami pamięci nieudanymi symptomami lub świadectwami - traumy przesłoniętej lub ujawnionej przez język. Zauważyłam, że rzekomo dobrze wiemy, co zrobić $\mathrm{z}$ wiedzą o ranach, których nie zadano naszym ciałom. Gayatri Spivak często wypowiada się o odpowiedzialności uprzywilejowanych adresatów listu, aby przełożyć siebie samych na języki, których nie będzie dane nam się nauczyć, abyśmy stali się podatni na zranienie w języku podmiotu poddanego dominacji, zakładając, oczywiście, że uda nam się ją/jego spotkać8. W słowie rana nie ma jednak niczego przezroczystego lub uniwersalnego, czy chodzi o zapis fotograficzny w ciele, czy w gatunku świadectwa. Świadek zawsze przybywa zbyt późno, to znaczy wiedza zawsze wiąże się ze stratą, a próby naprawy $\mathrm{z}$ daremnością. Wystudiowana pokora komentarza o niewymowności w obliczu przygodnego obiektu (interpretacyjnego) pożądania nie jest wyłącznie jedyną postawą etyczną uprzywilejowanych, lecz także żądaniem zaznaczenia funkcji zajmowania miejsca jako cechy dystynktywnej wszelkiego posttraumatycznego oznaczania.

6 S. Goulding Curiosity, w: tejże The Eight Technologies of Otherness, Routledge, London 1997, s. 16$-18 ;$ J. Derrida How to Avoid Speaking: Denials, transl. K. Frieden, w: Languages of the Unsayable: the Play of Negativity in Literature and Literary Theory, eds. S. Budick, W. Iser, Stanford University Press, Stanford 1987, s. 3-70.

7 M. Renov 'Video confessions', w: Resolutions: Contemporary Video Practices, eds. M. Renov, E. Suderberg, University of Minnesota Press, Minneapolis 1996, s. 94. 
Jeśli chodzi o autentyczność świadectwa i historyczny optymizm, twierdzenie o cielesnym realnym skrytym za przejrzystością reprezentacji traumatycznej stało się równie wymagającą normą. W tych warunkach ujawnia się nowe pole ekspertyzy, obejmujące ten szczególny problem, wytwarzające przypadki i objaśnienia, które, oddając sprawiedliwość tematowi, nadmiernie nie próbują go objaśnić. Co jednak się wydarza, gdy forma świadectwa normalizuje się z czasem, w procesie repetycji? Zamiast tworzyć przestrzenie przezroczystości, które z góry zaznaczają wartość sprawczości świadectwa, chciałabym przemyśleć gatunki i normy, skojarzone z nimi, które organizują współczesne obiegi traumy w heterotopiach intymności słuchaczy.

Co to znaczy wytropić formę? Forma nie jest tożsama z gatunkiem, który odnosi się do konwencjonalności prawa interpretacji. Aby gatunek zaistniał jako norma, wpierw musi krążyć jako forma, pozbawiona ontologii, wytworzona jednak przez powtórzenia, które czytelnicy nauczyli się odczytywać jako niechybnie zorganizowane. W najprostszym znaczeniu dociekam tutaj, co to znaczy, że nie-prawnicze świadectwo stało się tak popularną formą, której autorytet odgrywany jest w określonym gatunku. Chciałabym zanalizować następujące terminy i ich związki w formie świadectwa - jako prawo, gatunek, ucieleśnienie, wiedza.

Pozwolę sobie teraz przeformułować dotychczasowy wywód w ramach przeciw-liberalnej teorii formy. Jak już dowodziłam w innych tekstach, abstrakcja uruchamiana przez prawo jest zarazem sceną formy i bezkształtu, nadmiarowego ucieleśnienia oraz wygnania i milczenia ${ }^{9}$. Prawo reprezentuje strukturę, która umożliwia wyobrażoną bezkształtność zuniwersalizowanej podmiotowości, a- lub antykształtność, w której podmiot poddany reprezentacji można uznać za wolny od porzucenia w zanegowanym ciele lub cielesnym przeznaczeniu. Stąd, reprezentacja to powszechnik, którego przeciwieństwo zazwyczaj nazywamy „ucieleśnioną szczegółowością?. Jednakże w pewnych okolicznościach zanegowany podmiot nie jest przede wszystkim naznaczony przez odkrycie swojej nazbyt łatwo pojmowalnej cielesności, lecz własną anonimowość. Ta anonimowość odbija i odwraca bezkształtność uniwersalnego podmiotu, uprzywilejowaną przez prawo oraz pojęcie abstrakcyjnej podmiotowości.Trudno mówić o anonimowości neutralnej lub

9 L. Berlant The Anatomy of National Fantasy, University of Chicago Press, Chicago 1991; L. Berlant National Brands/National Bodies: Imitation of Llife, w: The Phantom Public Sphere, ed. B. Robbins, Minnesota University Press, Minneapolis 1993, s. 173-208. 
utopijnej, ma ona charakter agonistyczny ${ }^{10}$. Podważa to nasze wyobrażenie o pojmowalności i jasności tego, co szczegółowe, które zazwyczaj oznacza tak jakby zawsze kształtowały je okruchy przeżytego doświadczenia, które można sprawdzić. Jako że nieuniwersalny podmiot jest w równym stopniu negowany i kształtowany przez prawo, jego/jej bezpieczeństwo i fizyczne przeżycie wymaga jeszcze głębszej anonimowości. Ponadto natarczywość jego/jej pozycji powtarza się w naszej anonimowości wobec tej osoby, gdyż nawet podpisane listy prawie zawsze oznaczają odmienność, zaledwie pusty dźwięk. Bezosobowy, intymny list do nieznajomego: to wyznacza prawo gatunku w formie świadectwa.

Wiemy jednak, że niektóre palące potrzeby są bardziej palące od innych. Obecnie w Stanach Zjednoczonych, i przez 25 lat wcześniej, ta modalność performatywu stała się narzędziem ekspresji dowolnych dolegliwości, co grozi wygładzeniem wyboistej drogi traumy. Wyrobienie sobie pojęcia o tym trybie autoprzekładu i rozpowszechniania to dostrzeżenie, że czasami staje się też czymś innym, bez względu na treść: podkreślaniem, że „ja” to traumatyczna historia, nieustannie powtarzana, w tych powtórzeniach niczym opera mydlana, melodramat i aria"1. Jej modalność jest rytmiczna, bardziej przypomina jednak wiersz wolny umieszczony w sonecie. Skoro te konwencje podmiotowości przekształciły się w znaki przepełnione pragnieniem obecności, przyjęły konwencje, dajmy na to, muzyki pop. Wzniosłość podkreślono wyraźnymi pulsacjami, wykonywaniem prostych dźwięków, plumkającym hałasem banalności. Skoro teksty nie są godne pamięci, chociaż w nią zapadają, forma staje się przekazem, co grozi neutralizacją bezwzględnego żądania w treści.

Takie ryzyko zawsze towarzyszy uniwersalizacji. Nie chciałabym tutaj powtarzać argumentu Adorno, że np. niezmienna synkopa (w jazzie) otępia umysł, lecz że siła przekonywania gatunków świadectwa może teraz stać się naśladownictwem otępiających lub banalizujących cech powtórzenia. Różnica leży w niestabilnym temacie zakłóconych, podobnych do czkawki form, pojawiających się w historiach traumatycznych: przewidywalny temat prowadzący do nieuchronnych powtórzeń, które jednak przeszywają wolę, by

10 B. Anderson Imagined Communities: Reflections on the Origin and Spread of Nationalisms, Verso, London 1983; L. Berlant The Queen of America Goes to Washington City: Essays on Sex and Citizenship, Duke University Press, Durham, NC 1997; L. Bersani Is the Rectum a Grave?, "October" 1987 No. 43, s. 197-222; I.M. Young Throwing Like a Girl and Other Essays in Feminist Philosophy and Social Theory, Indiana University Press, Indianapolis 1990. 
przestać czuć się istotnym lub pozostawionym przy życiu, a co za tym idzie straumatyzowanym.

W tej wersji eseju moje różnorodne archiwum uległo kompresji ze względu na brak miejsca. Gdybym je tutaj zamieściła w całości, pochodziłoby głównie ze Stanów Zjednoczonych: jego obiekty można ze sobą porównywać, gdyż autobiograficzne świadectwo służy jako pierwszorzędny formalny materiał dowodowy, że chwila obecna to historyczna teraźniejszość, w której osoba lub wspólnota tyle już wycierpiały, że ich życie trwa dalej, nie zdołało jednak wykroczyć poza traumę definiującą to teraz. Z historycznego punktu widzenia interesuje mnie gwałtowne tworzenie „sieci kobiet” w Stanach Zjednoczonych: wchodzą w to trendy w dziewiętnastowiecznym popularnym dziennikarstwie aż po współczesną, masową sferę publiczną. Ogólnie rzecz ujmując, to archiwum łączy formę świadectwa lub „skargi”, wydobywającą z milczenia kobiecą wiedzę, z innymi trybami ekspresji takimi jak komentarz z offu i ścieżka dźwiękowa, w której ujawnia się "gdzie indziej" realistycznej narracji w literaturze modernistycznej (na planie estetycznym lub innym). Pomyślcie tylko o miejscu meliczności (muzyki) w „filmie dla kobiet”, jak wyraża niewyrażalne. Takie właśnie połączenia przyszywają kobiety do rozmaitych scen cierpienia, potwierdzając i znosząc różnicę, np. między listem od nieznanej kobiety na wojnie a listem od nieznanej zakochanej. Kiedy jednak kobieta publicznie składa świadectwo „jako kobieta”, pozostaje nieznaną: jej wiedza naznaczona jako coś, co nigdy nie stało się publiczną normą, nawet jeżeli jej rewelacje nie przynoszą niczego nowego ${ }^{\mathbf{1 2}}$.

Rozpoznawalna dzięki zwrotowi ku „ja” forma świadectwa zmusza cię, abyś zwrócił na nią uwagę, nawet jeśli zawiera klisze. Jednakże świat monologów, odbijających się od siebie niczym cząsteczki materii, nie sprawia wrażenia przestrzeni emancypacji. Bardziej pasowałoby określenie „nadający siłę”: logika współczesnego, konwencjonalnego świadectwa przywołuje pragnienie, by pojawiły się potężniejsze, rebelianckie podmioty w świecie, którego parametry i hierarchie wartości przyjmujemy za pewnik. Może to rodzić wrażenie normatywności i dyscyplinowania, sceny przyuczania do właściwego formalizmu podmiotu. Jeśli jednak nie ma nic zdrożnego w samej autobiografii, to pytanie „i co z tego”, nieuchronnie pojawiające się w jej posttraumatycznych wersjach, należy uzupełnić o pytanie, które moglibyśmy sformułować „dla czego”"13. Opo-

L. Berlant, M. Warner Sex in Public, "Critical Inquiry” 1998 No. 2, s. 547-566.

Pierwsze pytanie "so what" odnosi się do znaczenia jakiejś obserwacji, drugie "for what" jej praktycznego zastosowania [przyp. tłum.]. 
zycyjna wiedza kobiet (oraz innych podmiotów konwencjonalnie łączonych z cielesnością) zawsze niesie ze sobą brzemię rzekomej porażki w osiągnięciu wystarczającej bezosobowości. W jakim celu opowiadana jest historia? Zadanie tego pytania nie równa się stwierdzeniu, że retoryka traumy jest $z \nmid a$, chodzi raczej o najprostsze twierdzenie, że jest to retoryka.

\section{O gatunku i historii: to jest, prawo kliszy}

Może pojawić się wrażenie, że zbyt wielką wagę przykładam do banalizujących skutków powtórzenia. Spieszę wyjaśnić, co stoi za tym podkreśleniem. Judith Butler dowodzi w The Psychic Life of Power, że z psychoanalitycznego punktu widzenia, nauczono nas kochać prawo i dostrzegać jego dobro w nas samych $^{14}$. Historia świadectwa jako gatunku transgresywnego musi rozpocząć się od tej pierwotnej wymiany, odbicia formalnych aspektów świata w trybach przyrzeczonej pojmowalności, w której instytucje napotykają osoby i czynią je społecznymi. W tej domenie spotykają się genealogie marksistowskie i psychoanalityczne: dla Negta i Klugego, Laplanche'a i Žižka fantazja to w przybliżeniu inny świadectwa; ono także wytwarza poczucie pseudociągłości między osobą a tym, co społeczne ${ }^{15}$. Gdy działa fantazja, nie odczuwa się nieciągłości między sobą a światem. Kiedy do głosu dochodzi masowa fantazja, tak jak w identyfikacjach narodowych, poczucie takiej ciągłości odzywa się u przedstawicieli politycznej prawicy. W konwencjonalnym ujęciu, forma indywidualności w kulturze liberalnej poddaje cenzurze nieciągłość między, dajmy na to, jednostkowym samorozumieniem oraz znaczeniem aktów między reprezentacją i zdarzeniem, głosem i sprawczością, a nawet krwią i losem narodu. W istocie marzenie senne liberalnej sfery publicznej domaga się tej nieciągłości: aby państwo mogło kontrolować wypowiedzi, możliwość ich rozpowszechniania, zrzeszania się w grupach politycznych oraz tworzenia praktyk przeciwnormatywnych, wypowiedź należy oddzielić od obywatelstwa, co czyni ją paradoksalną w domenie prawa. W sferze

14 J. Butler The Psychic Life of Power: Theories in Subjecton, Stanford University Press, Stanford 1997.

15 S. Žižek 'The Spectre of Ideology', w: tegoż Mapping Ideology, Verso, New York 1994, s. 28-9; S. Žižek Przekleństwo fantazji, przeł. A. Chmielewski, Wydawnictwo UWr, Wrocław 2009; O. Negt, A. Kluge Public Sphere and Experience: Toward an Analysis of the Bourgeois and Proletarian Public Sphere, transl. P. Labanyi, J.O. Daniel, A. Oksiloff, University of Minnesota Press, Minneapolis 1993; J. Laplanche, J.-B. Pontalis Fantasy and the Origins of Sexuality, w: Formations of Fantasy, eds. V. Burgin, J. Donald, C. Kaplan, Methuen, London 1986, s. 5-44. 
publicznej wypowiedzi przysługuje więcej praw, gdyż można ją oddzielić od konkretnych ciał.Zdolność mówienia to dowód na ukształtowanie osoby jako podmiotu prawa i wynikającej z tego faktu skutecznej ochrony prawnej jako obywatela. Tym, co poddano cenzurze w tym kontekście, to jest wyrzeczono się, jest nieciągłość między następującymi pozycjami: mówcy/agensa, podmiotu prawnego, obywatela.

W ten sposób wracam do tematu prawa. W nim świadectwo ma instrumentalny cel: to materiał dowodowy w argumentacji skonstruowanej przez kogoś innego, oskarżyciela w sprawie. W prawie materiał dowodowy przedstawiany jest zgodnie ze ścisłymi zasadami, które dotyczą kwestii ideologicznych takich jak znaczenie dla sprawy i jej materii - anonimowe dowody i pogłoski, o których już tu słyszeliśmy, są zakazane. Dowody prawne stają się częścią archiwum możliwego do wykorzystania jedynie wtedy, kiedy pasują do jego reguł syntaktycznych. Ten schemat znajdujemy w centrum przyjemności prawa: jego maszyna przezroczystości chroni nas przed doświadczeniem własnej negacji. Każdy, kto doświadczył osobistej nieistotności wobec systemowej negatywności społecznej, zrozumie mój opis praw człowieka i liberalnego prawa jako kochanka na białym koniu, który doprawdy czasem się pojawia, i to w taki sposób, że zmieniają się zasady działania świata, oczyszczając przestrzenie sporu i przygodności, aby przedstawić ciągłość, neutralizując tym samym jej niestabilne pozostałości. Nie znaczy to, że występuję przeciw prawu, miłości i przywiązaniu, chciałabym odmierzyć formę, związek między gatunkiem świadectwa jako wyznacznikiem podmiotowości prawnej/wyznania z jednej strony a tymże gatunkiem jako formą autoekspresji, który zaznacza temporalną konieczność, żądanie wobec czasu oraz tryb autentyczności z drugiej. Ta druga forma czerpie z długiej historii tworzenia autobiografii, blisko związanej z prawem, religią i kulturą terapeutyczną, modalnościami oczyszczania podmiotów i świata społecznego, powiązanymi z nowoczesną wiarą w intencjonalny podmiot $\mathrm{i}$ jego widzialne skutki. Jednakże opozycyjna wiedza zarządzana przez nowoczesny gatunek świadectwa nie skupia się wcale na intencjonalnym podmiocie, lecz na podmiocie powstałym bez żadnej intencji; nie uprawomocnionej osobie, lecz zanegowanym podmiocie, którego negacja czyni ją/jego kolektywnym i pomniejszym, jak stwierdzili Deleuze i Guattari ${ }^{16}$. Autobiografia to zawsze

16 G. Deleuze, F. Guattari What is a Minor Literature?, w: Out There: Marginalization and Contemporary Culture, eds. R. Ferguson, T.T. Min-Ha, M. Gever, C. West, The MIT Press, Cambridge, MA 1992. 
tryb dodawania napisów (autocaptioning), chcę odkleić konieczność takiego performansu świadectwa od jego tradycyjnej formy, aby zrozumieć rosnący formalizm systemowo zanegowanego podmiotu, wyizolowanego przez tę negację i jednocześnie włączonego w świat wspólnotowy.

To znaczy, śledzimy współczesną historię "naszego" pojmowania z pozycji oświeceniowych podmiotów, które czują, że podmiot istnieje, gdyż zinternalizował wszystkie gatunki dyscypliny, fantazji i wiary, wywodzące się z prawa i religijnego wyznania od czasów Augustyna. Foucault poczynił tu pewne rozstrzygnięcia pojęciowe, co sprawiło, że te gatunki zaczęto postrzegać jako opresyjne, lecz, jak zauważa Michael Renov, Foucault „przyciąga naszą uwagę do dynamicznego i proteuszowego charakteru wypowiedzi świadectwa"17. Dwa czynniki odróżniają podejście francuskiego myśliciela od modelu psychoanalitycznego: zainteresowanie bezosobowością sceny, na której prezentujemy nasze osobiste podmiotowości, oraz formalizmem może nie gatunku jako takiego, lecz racjonalizujących taksonomii, opisujących miejsce podmiotu przez kategorialne przypisanie. Argument psychoanalityczny zaczyna się z kolei od traum intersubiektywności. Doświadczenie „przywiązania” pojawia się dopiero wtedy, gdy niemowlę rozpoznaje przygodność przywiązania; w międzyczasie pragnienie i miłość do prawa pochodzą z przyjemności innych wywołanej naszą piśmiennością, z naszej przyjemności czynienia ich pojmowalnymi dla nas. Stajemy się dostępni jako podmioty o tyle, o ile wchodzimy w tę transakcję pojmowalności. Kiedy podmiot negocjuje podporządkowanie się porządkowi, świat składa obietnicę, że to podporządkowanie zostanie docenione i odbite w wymiarze społecznym, stąd przewodnie prawo, które wydaje się pochodzić od podmiotu, może pozostać ogólnym wyznacznikiem przejrzystości, gdy w istocie brak takiego wskaźnika.

Przygoda kultury liberalnej z prawem jako tym, co wydobywa najlepsze z ludzi, nie wymaga potwierdzającego go obrazu ciała wykonującego jakiś akt lub się od niego powstrzymującego, lecz wyjaśnienia obrazu związanego z tobą. To znaczy, liberalizm to kultura napisów, tego, co można wyczytać z ciała i rozpowszechnić między ludźmi lub instytucjami zdolnymi zweryfikować, czy jest prawdziwe. Stąd świadectwo jest także praformą liberalnej jednostkowości, o tyle, o ile wypowiada je konwencjonalny byt; historię jako świadectwo można odczytać z podmiotu i puścić je w obieg, tworzy archiwum losu podmiotu jako znaczenia, skupia jego/ją w tekście jako podmiot 
poddany prawom pojmowalności. Derrida wykazuje w Ear of the Other, że podmiot oddaje siebie sobie, kiedy podsłucha swoją autobiografię i ulegnie pokusie, żeby się z nią utożsamićn ${ }^{18}$. Dlatego też idea zgłoszenia „apelacji” ma tyle erotycznego i desperackiego uroku w kulturze abstrakcji, którą wyraża fantazja liberalnego prawa o dobrej osobie: jeśli jednostka przegrywa sprawę mimo swojego świadectwa, zgłasza apelację, gdyż jej historia była wcześniej niewystarczająco atrakcyjna ${ }^{19}$. Co gorsza, stała się odrzucająca. Nie dała zwycięstwa. Istnieją zasady i normy dotyczące prawa do złożenia apelacji, stawka porażki jest wystarczająco jasna: wymowność albo życie.

Badacze i badaczki retoryki z pozycji feministycznych i antyrasistowskich wielokrotnie dowiedli, jak trudno przychodzi zanegowanym podmiotom odnalezienie trybu dodawania napisów, który ma szanse uznania za wymowny lub podmiotowy w kulturze pojmowalności-jako-prawa. Dlatego też o zanegowanych słyszymy dziś ciągle, że skarżą się na melancholię, handlują stratą, która nigdy nie jest zupełna, odczuwają formę traumy nieustannie tykającej i domagającej się wypowiedzenia. O co chodzi w przymusie powtarzania, który przywiązuje podmiot do negacji? Po raz wtóry, modele Foucaulta i psychoanalizy się różnią: ten pierwszy ogniskuje się na kapitale kulturowym zgromadzonym przez uczestnictwo podmiotu w gatunkach pojmowalności. Ronald Fairbairn, psychoanalityk z początku XX wieku, próbował zrozumieć problem przyjemności w następujący sposób: jeśli Freud miał rację, że podmiot poszukuje przyjemności, jak wyjaśnić rzekome uzależnienie podmiotu od sceny porażki, co grozi utratą optymizmu potrzebnego do przetrwania? Fairbairn pracował w Szkocji $\mathrm{z}$ adoptowanymi dziećmi i sierotami, straszliwie traktowanymi przez rodziców: wielokrotnie najgorzej traktowane dzieci były tymi, które przywiązywały się najmocniej. Doszedł do wniosku, że dla Freuda przyjemność nie jest przyjemnością, lecz czymś formalnym, jak przywiązanie, zwykłym powtórzeniem, a nie czymś, co skłonni bylibyśmy nazwać pragnieniem: jesteś zmuszony powtarzać scenę porażki właśnie dlatego, że się nie udała, to niepowodzenie splątało się z optymizmem, że uda się w końcu uwieść prawo własnym apelem, mimo że jest zupełnie jasne, że definicja jednostki jako pojmowalnej zależy od jej wcześniejszej negacji. Negację tę mogą

18 The Ear of the Other: Otobiography, Transference, Translation: texts and discussions with Jacques Derrida, English edition ed. by Ch. McDonald; transl. P. Kamuf, Schocken Books, New York 1985.

19 Berlant odwołuje się tutaj do wieloznaczności słowa „appeal”: apelacja oraz urok/atrakcja [przyp. tłum.]. 
przysłaniać inne znaki, lecz nigdy nie sposób jej całkowicie wymazać jako warunku pojmowalności/możliwości jednostki ${ }^{20}$.

Czy ta koncepcja świadectwa jako dodawania napisów do losu podmiotu to teoria masochizmu podporządkowanych, forma mylnego optymizmu na rzecz miłości do prawa? Spójrzmy na wyjaśnienie Freuda, skąd bierze się kobiecy masochizm. Ojciec psychoanalizy definiuje go po prostu jako skierowanie do wewnątrz gniewu, na który brak usankcjonowanego miejsca w świecie społecznym. Z tego punktu widzenia, mimo jego poglądu, że kobiety mają słabsze poczucie sprawiedliwości z racji mniej stabilnych granic własnych napisów lub kontroli nad nimi, znaczyłoby to, że melancholia społecznie zanegowanych i przymus tworzenia scen świadectwa, które potwierdzałyby destabilizujące pragnienie pojmowalności prawa, jest jednocześnie odwróconą agresją, zarówno liberalnym apelem o uwodzicielskiej sile prawa, jak i impulsem wymierzenia policzka jego okrutnej twarzy. W związku z tym możliwe jest, że postrzeganie gatunku świadectwa jako rodzącej się estetyki klasowej, która postawiła sobie za cel przezwyciężenie wyraźnego stanu opatrzenia napisami podporządkowanego ciała, jest wyrazem traumy (złamanie prawa przez nie same w wyniku zanegowania jego podmiotu), wywołuje świadectwo (apel o jej powtórne pojawianie się) oraz odzyskuje pojedynczy wers napisów czy typifikacji (wyrażającej pragnienie istnienia świata, w którym samowiedza jednostki lub estetyka „ja" zostałyby rozpoznane jako podmiotowość).

W tym modelu kultura nadawania napisów przemawia retoryką społecznej mniejszości do społecznej większości: to piękna melodia, którą prawo mogłoby włączyć w banalny podkład muzyczny obietnicy własnej jasności. Jest to jednak, jednocześnie, wielotonalna ścieżka muzyczna Innego świata, półświatka, a nawet podziemia, któremu strukturę nadaje nieudane świadectwo podporządkowanych. Być może świadectwo nie przekonało prawników albo gwałciciela, społeczności lub władz.W innym tekście nazwałam tę scenę pedagogią nieudanego nauczania: wiedzy wywodzącej się z optymizmu, lecz pokonanej przez rozczarowanie ${ }^{21}$. Przejmuje te dźwięki poddane tekstualizacji i tworzy z nich rodzinę, której nigdy nie miałeś, w świecie, który nigdy do ciebie nie należał, ani nie był dla ciebie przeznaczony ${ }^{22}$. Dając świadectwo tej

W.R.D. Fairbairn Psychoanalytic Studies of the Personality, Routledge, New York 1994.

L. Berlant The Queen of America..., 1997.

M. Renov 'Video confessions', s. 94. 
porażce, wyrażasz pragnienie, aby zobaczyć się na zapisanej stronie, bardziej spójny, niż kiedykolwiek się czułaś/eś, nie jako bezkształtne rozproszone „ja”, które zwykle nosisz ze sobą. Teraz stałeś się historią, mimo że to historia porażki, z zakończeniem, którego nie zamyka ostatnia kropka, lecz czeka je kolejne życie we wspólnocie tekstowych świadków, poszukujących siebie nawzajem, aby stworzyć świat pamięci, gdzie nic nie zostanie zapomniane, wstyd ulegnie unicestwieniu, zniknie samotność, a słowa nabiorą wagi (tym razem) jako wiedza. W końcu łączy się to z czymś jak „ja”, a zdolność pisania czyni cię bohaterem historii, która zarówno należy do ciebie i poza ciebie wykracza. Ta odmiana świadectwa odwraca implikację, lecz nie formę traumatycznej historii, gatunku wydarzenia zbyt-późnego-lecz-nigdy-nieukończonego. Dajesz świadectwo: publiczność jest sędzią i ławą przysięgłych. Oskarżasz: nieobecne korzenie przemocy, które naznaczyły twoją przygodność, stanęły przed sądem. Wydajesz wyrok: na zewnątrz istnieje świat zaniedbania i przemocy, nie ten, gdzie intymność i dystans mają właściwy rytm, obecność towarzyszy nieobecności, a bycie-z nie jest przytłaczające, ani nie wywołuje wstrętu. Straszliwe uczucie bycia i nieposiadania żadnej struktury utrzymującej przy życiu, poza własną wolą i pamięcią, zostaje więc dodane do sceny pierwotnej w celu nauczania jako warunku przeżycia. Jedynie nauczyciel rozumie skalę nieudanego wydarzenia i tylko on/ona ma sposobność i optymizm, aby powtarzać je dla coraz to nowych słuchaczy. Nie wolno umniejszać heroicznego pragnienia obecnego w tym trybie świadectwa, homeryckich porównań ocalałego z wojny, którego opowieść głosi obietnicę przyjemności oraz instrukcję unikania powtórzeń. Innymi słowy, forma wytwarza świat afektu wokół powtórzenia porażki w formie zwykłej wiedzy, wiedzy tak przygodnej, że grozi popadnięciem w czysty akademizm.

\section{Czysto akademickie świadectwo}

Stwierdziłam, że gatunek świadectwa stapia w sobie skomplikowaną historię przywileju i zgłaszania roszczeń. Większość dobrze znamy, od świętych tekstów, deklarujących obecność Boga w czyjejś podmiotowości aż po teksty polityczne, przyznające, że przemoc oddziela kogoś od normalnego świata, istniejącego lub nie. Co więcej, zauważyłam, że świadectwo nieuchronnie denotuje seksualność, nie tylko dlatego, że jądra (testes) etymologicznie wystają ze świadectwa (testimony). Seksualność bowiem włącza instytucje, które czynią pojmowalnymi szczególne cielesności w czasie teraźniejszym ich sprawstwa oraz w dłuższych okresach mierzonych w pokoleniach (lecz 
nie zdegenerowanych), narracyjność świadectwa, bez względu na to, czy $\mathrm{w}$ treści dochodzi do transgresji, zagraża oczywistości styku tego, co intymne z tym, co publiczne. Ponadto, co znajdujemy u Derridy w The Law of Genre, na dobrą sprawę kazirodcza relacja między obłąkanym powtórzeniem i właściwą pojmowalnością w nieunikniony sposób naznacza wiedzę pragnieniem. W szczególności widać to w brzemieniu noszonym przez strukturalnie podporządkowanych, polegającym na przymusie posiadania zbyt dużej wiedzy. Forma świadectwa uwalnia w świat ten nacisk na umysł wynikający z nadmiaru wiedzy przy braku władzy, czymkolwiek jest posiadanie władzy. Ta negatywność to cień banału wiedza to władza, definicji wiedzy nakierowanej na uznaną ekspertyzę, godne zaufania odniesienie, własność intelektualną. Przez szklany klosz wskazuje to na Priviledge of Unknowing Eve Sedgwick: brzemię wiedzy ${ }^{23}$. O ile homeopatia tekstu świadectwa ma na celu uzdrowienie zranionego ciała zanegowanej osoby, wiedza świadectwa polega na zrzuceniu z siebie wiedzy, która może utrudniać swoje powtórzenie, stając się nieokiełznana, przekładana przez innych.

Przypadkowa zbieżność teorii z moim pragnieniem skłania mnie do przywołania pomysłu Gerarda Genette'a, że historię bohatera, z której przemawia głos lektora (voice-over), możemy nazwać homodiegetyczną $q^{24}$. Komentarz z offu to kinowy sposób nadawania napisów, który wyrywa postać z widzianej przez nas cielesnej bezpośredniości do niewidocznej czasowości, tak jakby to obraz był duchem, zaś głos, materializujący się jako wiedza i komentarz, może powrócić do życia nieobciążony nieszczęśliwym ciałem, do którego nadal jest przywiązany. Samowiedza i narracja rywalizują z bolesnymi przyjemnościami kinowego ciała i mogą je przezwyciężyć. Homodiegeza, rozszczepienie głosu na bycie i jego przedłużenie, list wysłany przez publiczność do siebie w sposób wprowadzający zamieszanie w postrzeganie czasowości, jest czymś zupełnie innym niż podniecająca i przygnębiająca, wyłaniająca się modalność ścieżki dźwiękowej filmu muzycznego.

Od początku XX wieku związek między hollywoodzkimi studiami a przemysłem muzycznym miał tendencję do pionowej integracji: ścieżka dźwiękowa i bliskie jej obrazy długo były „takie właśnie”, przekazując sobie nawzajem

E. Sedgwick Privilege of Unknowing: Diderot's 'The Nun', w: tejże Tendencies, Duke University Press, Durham, NC 1993, s. 23-51.

24 G. Genette Paratexts: Thresholds of Interpretation, transl. J.E. Lewin, Cambridge University Press, Cambridge 1997; G. Genette Mimologics, transl. T.E. Morgan, University of Nebraska Press, Lincoln 1995. 
tryby upodmiotowienia, o których nie słyszano przed pojawieniem się kultury masowej ${ }^{25}$. Niedawno stało się jasne, że niektóre filmy są zaledwie dodatkiem do ścieżki dźwiękowej, zaś muzyka filmowa promowana jest zarówno jako reklama filmu, z którym czasami ma niewiele wspólnego, jak i prawda filmu, którą należy ustalić: jaki jest związek między segmentem rynku a społeczną tożsamością? Genette nazywa tę formę zewnętrzności aktywnością „heterodiegetyczną". Heterodiegetyczna podmiotowość rodzi się, gdy uprzednio nagrana piosenka niezwiązana jednak z aktorem lub gwiazdą wyraża wnętrze postaci. W telewizji tę konwencję ustanowiło Miami Vice ${ }^{\mathbf{2 6}}$. Don Johnson po ciężkim dniu przechodzi przez ciemny, opuszczony parking przy dźwiękach piosenki, dajmy na to, The Eagles. Nie ma wątpliwości, że znaczenie piosenki miało wyrażać prawdziwy charakter postaci granej przez Johnsona, jego seksualność i niewyrażalne wnętrze. W tym lokowaniu produktu piosenka denotuje system gwiazdorski, który można w filmie utożsamić z kapitałem kulturowym i sprzedać temu, kto ma wystarczające środki, w podobny sposób moda funkcjonowała od czasu związania się z przemysłem filmowym w latach $30 .^{27} \mathrm{Te}$ antologie muzyczne rzadko komponowane są jako „spójna partytura", wymagają zaś złożonych operacji finansowych i wizerunkowych między poszczególnymi artystami i studiami nagraniowymi. Nie chcę powiedzieć, że piosenki nie są w stanie wyrazić denotowanej relacji afektywnej: wprost przeciwnie sztuczność piosenki to właśnie podmiotowość nowoczesnego konsumenta, przynajmniej w pewnym zakresie.

Czyniąc podmiotowość bytem kolektywnym za sprawą będących owocem współpracy głosów odcieleśnionych innych, heterodiegetyczna ścieżka dźwiękowa prawdopodobnie podważa fanatazmatyczne ciągłości dodawania napisów przez podmiot, które opisałam wcześniej jako wyznacznik struktury liberalnej indywidualności ${ }^{\mathbf{2 8}}$. Niemniej jednak odtwarzane z playbacku wnętrze w muzyce pop przywołuje realizm szczytowego postmodernizmu, poczucie, że swojej autentyczności można doświadczyć jedynie jako nieautentyczność. Nie ma niczego cynicznego w tej piosence, wyrażającej prawdziwe

25 J. Mundy Popular Music on Screen: from Hollywood Musical to Music Video, Manchester University Press, Manchester 1999; R. Prendergast Film Music: a Neglected Art, W.W. Norton, New York 1992.

R. Prendergast Film Music, s. 286

27 J. Gaines, C. Herzog Fabrications: Costume and the Female Body, Routledge, New York 1990.

28 C. Flynn Strains of Utopia: Gender and Nostalgia, and Hollywood Film Music, Princeton University Press, Princeton 1992. 
uczucia w przewidywalnym języku, klisza i inne konwencjonalne tryby wiążą się z pragnieniem uproszczenia wszystkiego, co wydaje się przytłaczające i nienegocjowalne w świecie „na zewnątrz". Staje się więc światem „wewnętrznym" wtedy, gdy jej powtarzanie służy pocieszeniu, daje władzę nad pamięcią, jest przezroczysta i ekscytująca, ale nie przywołuje powtórnej traumy.

Czym różni się ten właściwy nastolatkom tryb prawdziwego uczucia, w którym skomercjonalizowana muzyka staje się podkładem muzycznym naszych osobistych/grupowych niejasności, od skądinąd dobrego podkładu muzycznego, to jest homodiegetycznego toposu, który ukazuje życie jako najprawdziwiej przeżywane w obszarach zróżnicowanej praktyki i powikłanej pamięci? Autobiograficzna trylogia Terence'a Daviesa, rozpoczynająca się od Dalekich głosów, spokojnego życia (Distant voices, still lives, 1988), korzysta w ten sposób z wiele ujawniającej ścieżki dźwiękowej. W pamięci ludzie zawsze walczą o przetrwanie, w pamięci zawsze znajdzie się piosenka towarzysząca nastrojowi życia, powstrzymująca się przed jego wyrażeniem. Muzyka pozbawia prywatności podmiot, któremu udało się przeżyć, w większym nawet stopniu niż kościół, pub lub klub piłkarski: pozbawia ludzi cielesności, aby zanotować coś wspaniałego, co jest niewyrażalne w codzienności. Davies zapamiętuje muzykę, ponieważ przypomina sobie znajomych śpiewających określone piosenki w szczególnych miejscach, odgrywających melancholię upragnionej obfitości i osobistej straty, które przywykliśmy utożsamiać z klasami pracującymi i rodziną nuklearną. To anonimowe ballady, a nie subiektywne świadectwa o czyichś prywatnych uczuciach. Ich obecność w tych przestrzeniach sprawia, że nadają się do życia, jednocześnie określając, dlaczego nie można tam żyć. Te ścieżki dźwiękowe nie są utopijne, w znaczeniu wyznaczenia horyzontu aspiracji. Davies umieszcza życie w pamięci i mentalności; jego filmy zachowują homodiegetyczny związek z piosenką, przekonanie, że ich przekład przez osobę, której historię właśnie słyszymy, jest czymś podobnym do powrotu do sceny, której jeszcze nie przeżył/a i może nigdy nie przeżyć. Denotuje ona melodramatyczną identyfikację odniesioną do mających nastąpić powtórzeń, jak też tych, z których udało się mu/ jej fizycznie wyjść. To jakby sfera mentalna była jednocześnie najbardziej ograniczoną i przestrzenią wyjścia, przynajmniej o ile autobiografia łączy się z niewyrażalnym przywiązaniem do traumy.

Obecnie dla wielu ścieżka dźwiękowa jako towar stała się takim wspomnieniem - walkman i boombox uczyniły wspólną muzykę bezosobową i przenośną, częścią społecznej aktywności, niewymagającej szczególnego doświadczania innych osób, która jednakowoż tworzy przynależność. 
Prywatyzacja jest obecnie bardziej publiczna, a jednocześnie sama wytwarza sferę publiczną, opowiadałam tu przecież historię, jak liberalna podmiotowość i roszczenia podporządkowanych do „prawa do narracji” doprowadziły do konwencjonalizacji nieopisywalnego, przekształcając je w news, a nie, w bardziej wzniosłą, komunikację. Jednakże błędem byłoby stwierdzenie, że pole, w którym ścieżka dźwiękowa staje się swoim akompaniamentem, jest w pełni nasycone wiarą w istnienie języka.

Nieustającą zdolność ścieżki dźwiękowej poruszania się w konwencjach narracji traumatycznej nie w stronę wspólnej przyjemności, lecz zatoru, wspaniale przedstawiono w filmie Magnolia (1999) Paula Thomasa Andersona. Magnolia nie jest musicalem. Komentarz z offu poucza nas jednak, że nic nie dzieje się przypadkiem i nic nie jest nieplanowane. Film pokazuje zbiegi okoliczności: dramatyczne, przestrzenne i historyczne - zbieg okoliczności jako społeczna zależność i ideologiczna wymowa. Oczywiście sceną tych zdarzeń jest rodzina, ten film, jak obecnie wiele innych, przedstawia męski protest przeciwko zwyczajnym kosztom intymności, który, pozbawiony wymiaru politycznego, nie ma publicznej ani sprawczej okazji do zdziałania czegokolwiek innego niż zniszczenie, negacja, krzywda i morderstwo. Optymizm filmu - w końcu Tom Cruise, zbrukany przyrodni syn, opiekuje się Julianne Moore, macochą i niedoszłą samobójczynią, nie wydaje się wcale antyedypalny. Jednak w samym środku numer rewiowy powstrzymuje popęd narracyjny: wszystkie postaci stają się „przypadkowe”, w różnych wątkach, czasach i przestrzeniach, i śpiewają: "It's not going to stop, it's not going to stop, it's not going to stop, 'till you wise up... so just give up" ${ }^{29}$. W teledysku do tej piosenki piosenkarz Aimee Mann to duch, unoszący się nad śpiewającymi bohaterami, których w filmie odosobniono w popowych podmiotowościach. Przytłacza to, że film odzyskuje znaki szczególnejednostek, kiedy nie udaje się wywołać irytacji publiczności (recenzje są w tym względzie podzielone). Wydaje się nieludzkie przedstawiać osoby jako w zasadzie takie same po tym, jak wpadły do celi odosobnienia doświadczenia traumatycznego. To jakby szczegóły były nieznaczące, pozbawione materii, jak duchy. Na podobieństwo autorów piosenek pop i ich niepokojących linijek tekstu lub, ,ja" wraz z intencjami, szczegóły to co najwyżej przypis lub epitafium fantazji woli w sprywatyzowanym świecie.

Gorąco pragnąc kontroli nad znaczeniem swojej prostoty, podmioty prawdziwego uczucia zwracają się do wewnątrz: widzimy jednak, że śpiewają tę samą piosenkę. Ugrzęźli w społecznym powtarzaniu, wytwarzają piękno 
zamiast rozumienia, lub tworzą piękno, aby pokazać, że zostali pokonani przez pragnienia, zdradzeni przez intymność, wyszydzeni przez instytucjonalną wiaręi upokorzeni przez optymizm. We współczesnym świecie zwykłej traumatycznej podmiotowości ta relacja do konwencjonalnego charakteru niejednoznacznego stosunku do pasji wzbudzanych przez traumę rzadko przedstawiana jest z tak zaskakującą niezgodą na zaprzeczenie, a jednocześnie z takim oddaleniem, formalizmu. Magnolia przypomina nam, że to właśnie wydarzenie przemiany czegoś skomplikowanego w coś prostego przy użyciu przemocy jest doświadczeniem traumatycznym i, o ironio, bardzo często fantazją o jego pożądanym zakończeniu.

Przełożył Tomasz Łysak

\section{Abstract}

\section{Lauren Berlant}

UNIVERSITY OF CHICAGO

Trauma and Ineloquence

This is a paper about trauma and ineloquence, violence and banality, and the utopian conventions of self-expression in liberal mass society: the U.S. is the scene of the case. The essay pursues relations among the post-traumatic reparative contexts of the law, religion, therapy and popular culture, all under the sign of autobiography. These domains articulate generic conventions of self-expressivity with the formalism of selfreflective liberal personhood. They link norms of expressive denegation to genres that conventionalize, and make false equivalents among, diverse traumatic consequences. When scenes of post-traumatic ineloquence morph into modes of transformativestyle rhetoric, does the eloquent form distract from, become a mask for, or intensify the unreachable or inarticulable thought that wants to change the norms of negation? A short history of the soundtrack as a site that marks the centrality of ineloquence to traumatic expression condenses the paradox of the moment, where a post-traumatic desire to become undefensive meets up with pop banality and therapeutic cliche.

\section{Keywords}

trauma, ineloquence, law, testimony, mass culture 